\title{
FAKTOR-FAKTOR YANG MENYEBABKAN KETERLAMBATAN PENYUSUNAN ANGGARAN PENDAPATAN DAN BELANJA DAERAH (APBD)
}

(Studi Pada Pemerintah Daerah Kabupaten Sarmi Tahun Anggaran 2010-2012)

\author{
Helen Aprila Maniagasi ${ }^{11}$ \\ Elitha Bharanti ${ }^{12}$ \\ ebonifasia@yahoo.com \\ Ferdinandus Christian ${ }^{13}$ \\ kotaraja_0112@yahoo.com
}

\begin{abstract}
The objective of this research was to examine the determinants of delays in Preparations of Regional Revenue and Expenditure. This study was conducted in Sarmi Regency. The population was member of budget board in the House of Representative, budget team from the government agencies and government officials from each work units. There were 60 respondents using a direct survey to collect data. A multiple regressions were employed to empirically test research hypotheses.

The research revealed that relation between executive and legislative positively associated with delays in preparations of Regional Revenue and Expenditure. In other words, the better relation between executive and legislative are likely to lower the delays in preparations of Regional Revenue and Expenditure in Sarmi regency. Also, the educational backgrounds positively influence delays in the preparations of Regional Revenue and Expenditure. It means that advancement in educational backgrounds are likely to lower delays in preparations of Regional Revenue and Expenditure in Sarmi regency. Another factor was performance indicators which positively associate with delays in preparations of Regional Revenue and Expenditure. This infers that increase in performance indicators will likely to lower delays in preparations of Regional Revenue and Expenditure in Sarmi regency. Meanwhile, commitment was not supported.
\end{abstract}

Key words: Delays in preparations of Regional Revenue and Expenditure, relation between executive and legislative, educational backgrounds, performance indicators, preparations of Regional Revenue and Expenditure

\section{PENDAHULUAN}

Menurut UU 33/2004 tentang perimbangan keuangan antara pemerintah pusat dan pemerintah daerah, APBD adalah rencana

\footnotetext{
11 Alumni Mahasiswa Magister Keuangan Daerah Universitas Cenderawasih

12, 13 Staf Dosen Jurusan Manajemen Fakultas Ekonomi dan Bisnis Universitas

Cenderawasih
} 
keuangan yang dibuat pemerintah daerah secara 4 tahunan melalui pembahasan dan persetujuan antara DPRD dan pemerintah daerah dan kemudian disahkan dalam peraturan daerah. Salah satunya aturan yang diterbitkan tersebut adalah Permendagri 13/2006 tentang pedoman pengelolaan keuangan daerah. Berdasarkan aturan tersebut telah diuraikan jadwal dalam menyusun APBD yang berlaku bagi seluruh pemerintah daerah di Indonesia. Namun, adanya aturan yang berisikan jadwal tersebut belumlah mampu untuk mengatasi fenomena yang tengah terjadi dalam penyusunan APBD di Indonesia. Fenomena tersebut turut menggelitik perhatian karena fenomena ini terjadi disebagian besar wilayah Indonesia. Fenomena tersebut adalah terjadinya keterlambatan dalam penyusunan APBD. Keterlambatan dalam penyusunan APBD ini telah terjadi dalam kurun waktu yang lama, bahkan di masa reformasi banyak pemerintah daerah yang masih terlambat dalam menyusun APBD. APBD yang mengalami keterlambatan dalam penyusunan tersebut merupakan APBD yang terlambat ditetapkan atau disahkan oleh pemerintah daerah bersama DPRD sebelum atau saat 31 Desember.

Keterlambatan penyusunan APBD telah melanda sebagian besar wilayah di Indonesia dan hal itu telah berlangsung pada kurun waktu yang lama bahkan hingga saat ini (Wangi dan Ritonga, 2010). Kabupaten Sarmi juga merupakan salah satu daerah yang tergolong mengalami keterlambatan dalam menyusun APBD khususnya APBD untuk tahun 2010-2012 APBD pada ketiga tahun anggaran tersebut disahkan pada kurun waktu antara 1 Januari - 31 Maret. Selain banyaknya daerah yang mengalami keterlambatan dalam penetapan APBD, adanya keterlambatan APBD dapat memberikan dampak negatif. Dampak yang ditimbulkan dari keterlambatan dalam penyusunan APBD secara umum adalah terlambatnya pelaksanaan program pemerintah daerah yang umumnya sebagian besar pendanaan program tersebut berasal dari APBD. Program yang terlambat dilaksanakan dapat 
berpengaruh pada pelayanan publik terhadap masyarakat. Fenomena terbaru sebagai dampak keterlambatan penyusunan APBD juga adalah diberlakukannya sanksi yang akan diberlakukan bagi daerah yang terlambat menyusun APBDnya. Kompas terbitan 21 November 2013 membeberkan pernyataan Direktur Jenderal Perimbangan Keuangan Kementerian Keuangan Marwanto Harjowiryono mengatakan pemerintah pusat akan memberikan sanksi kepada pemerintah daerah yang terlambat menyusun dan menyerahkan APBD 2013. Pernyataan ini lahir sebagai antisipasi dari dampak yang akan ditimbulkan karena adanya keterlambatan penyusunan APBD tersebut. APBD yang terlambat dalam proses penyusunannya dapat pula berpengaruh terhadap perekonomian daerah. Hal tersebut terjadi karena ketika APBD terlambat ditetapkan melebihi 31 Desember, maka dimasa APBD belum disahkan maka aliran dana dari sektor pemerintah akan terhambat dan itu memberikan pengaruh pada aliran uang atau transaksi di daerah dan pada akhirnya perekonomian daerah turut merasakan dampak dengan adanya kelesuan ekonomi.

APBD yang terlambat disahkan oleh pemerintah daerah dan DPRD dapat pula memberi peluang munculnya korupsi, sebagaimana dinyatakan (KPK,2008). Peluang korupsi tersebut dapat muncul dikarenakan adanya usaha untuk mengalihkan dana yang tersisa dari pelaksanaan program APBD ke dalam rekening pribadi. Dana yang tersisa berasal dari dana sisa anggaran program yang tidak selesai dilakukan karena terlambat dalam pelaksanaan proses awal. Pengalihan dana ke rekening pribadi tersebut membuka peluang terjadi penyelewengan dana APBD untuk kepentingan pribadi sehingga terjadilah korupsi. Kabupaten Sarmi juga termasuk daerah yang mengalami keterlambatan penyususan anggaran tersebut. Dampak yang timbulkan dari adanya keterlambatan APBD dapat pada akhirnya merugikan masyarakat selaku penerima layanan publik termasuk masyarakat di Kabupaten Sarmi dan hal ini bertentangan dengan tujuan 
pemerintah yang selalu berusaha untuk memberikan pelayanan terbaik bagi masyarakat.

Untuk mengatasi masalah ini seperti yang dikemukakan oleh Andika, (2006) bahwa langkah pertama atau yang utama yang harus ditempuh dalam rangka menemukan solusi tersebut adalah melalui identifikasi penyebab keterlambatan penyusunan APBD tersebut. Kenyataan yang ditemukan berdasarkan pilot study, yakni bahwa keterlambatan penyususnan APBD Kabupaten ini relative disebabkan karena adanya konflik yang terjadi seperti yang dinyatakan dalam tori keagenan.

Penyebab lainnya relatif bersumber dari sumber daya yang ada utamanya sumber daya manusia yang berkaitan dengan kompetensi penyusun APBD tersebut. Untuk hal ini hal penting yang perlu diperhatikan adalah kompensi penyusun APBD melalui latar belakang pendidikan mereka. Logikanya adalah jika penyusun APBD tersebut memiliki latar belang pendidikan yang mendukung maka kemungkinan terjadinya keterlambatan akan dapat direduksi. Faktor-faktor penyebab keterlambatan RAPBD Kabupaten Sarmi tahun 2010-2012. Beberapa faktor penyebab tersebut antara lain: Belum adanya Rencana Pembangunan Jangka Menengah Daerah (RPJMD) sebagai alat control pembangunan yang menggunakan APDB untuk mewujudkan visi misi Bupati dan Wakil Bupati, yakni satu hati, satu tujuan membangun sarmi dalam kebinekaan. RPJMD sebagai payung dan juga alat penggerak utama dalam penggunaan APBD Kabupaten Sarmi, tetapi RPJMD juga merupakan kerangka acuan pembangunan 20 tahun.

Keterlambatan Laporan Pertanggungjawaban dari SKPD, serta kinerja Tim Anggaran yang dipimpin oleh Sekda sebagai pengguna APBD. Lemahnya fungsi legislatif dalam memberikan pandangan akhir pada pra siding RAPBD Kabupaten Sarmi pada penetapan RAPBD menjadi APBD dalam sidang DPRD untuk selanjutnya menjadi perda Kabupaten Sarmi tahun Anggaran 2010-2012. Hal lainnya yang relatif 
menyebabkan terjadinya keterlambatan penyusunan APBD ini adalah kemampuan untuk menetapkan menentukan indikator dan target kinerja untuk setiap program karena kurangnya data-data yang diperlukan. Ini berarti adanya miss komunikasi dan koordinasi (baik yang bersinggungan dengan birokrasi maupun politik) diantara tim anggaran pemerintah daerah maupun DPRD, khususnya menyangkut indikator dan target kinerja yang teruang dalam prioritas anggaran dan alokasi anggaran pembangunan. Berdasarkan permasalahan diatas, maka tujuan dari studi ini adalah untuk mengetahui dan menganalisis pengaruh faktor hubungan eksekutif/legislative, latar belakang pendidikan, kinerja, komitmen, penyusun APBD terhadap keterlambatan penyusunan APBD di Kabupaten Sarmi.

\section{SISI TEORI}

\section{Teori Agency pada Organisasi Pemerintah}

Hubungan keagenan dalam teori agensi muncul ketika ada penugasan dari individu (prinsipal) kepada individu lain (agen). Mengacu pada Undang-Undang Nomor 32 tahun 2004 partisipan pada organisasi pemerintahan meliputi rakyat, bupati atau walikota, dan DPRD. Dalam undang-undang tersebut, bupati dan walikota mempunyai tanggung jawab atas perencanaan, pelaksanaan dan pertanggungjawaban program pemerintah sehingga berperan sebagai eksekutif. Mekanisme pemilihan bupati dan walikota oleh rakyat menunjukkan adanya pelimpahan wewenang dari rakyat kepada bupati dan wali kota. Hal ini menunjukkan bahwa Bupati dan Walikota berperan sebagai agen dan rakyat merupakan prinsipal dalam rerangka hubungan keagenan.

\section{Penyusunan Anggaran Pendapatan dan Belanja Daerah (APBD)}

Proses perencanaan dan penyusunan APBD, mengacu pada PP Nomor 58 Tahun 2005 tentang Pengelolaan Keuangan Daerah, 
secara garis besar sebagai berikut: (1) penyusunan rencana kerja pemerintah daerah; (2) penyusunan rancangan kebijakan umum anggaran; (3) penetapan prioritas dan plafon anggaran sementara; (4) penyusunan rencana kerja dan anggaran SKPD; (5) penyusunan rancangan perda APBD; dan (6) penetapan APBD.

Gambar 1.

Tahapan Penyusunan APBD

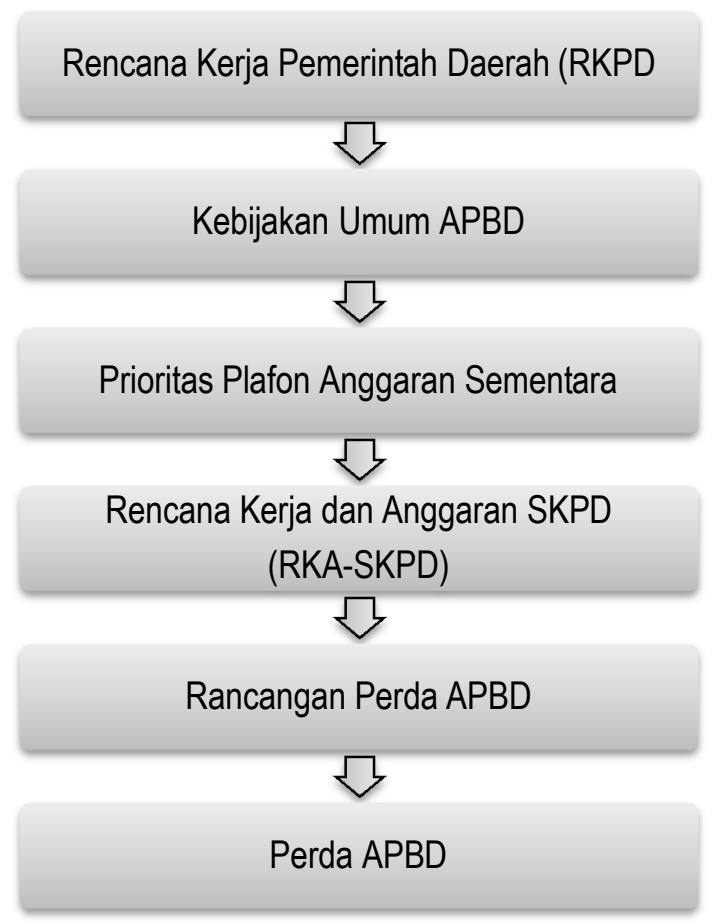

\section{METODE PENELITIAN}

\section{Uji validitas}

Uji validitas menunjukan sejauh mana tingkat efektivitas alat pengukur di dalam melakukan pengukuran (Agusty, 2006:16). Uji validitas dalam penelitian ini menggunakan rumus korelasi Product Moment Person, dimana valid atau tidaknya instrument dapat 
diketahui dengan membandingkan indeks korelasi Product Moment Person dengan signifikan 5\%.

Formula korelasi Product Moment Person adalah sebagai berikut;

$$
\mathrm{r}=\frac{n \sum X Y-\sum X \sum Y}{\sqrt{\left.n \sum X^{2}-\left(\sum \llbracket X\right)^{2}\right)\left[n \sum Y^{2}-\left(\sum Y\right)^{2}\right]}}
$$

Keterangan :

$\mathrm{n}=$ banyaknya sampel

$X=$ nilai atau skor $X$

$\mathrm{Y}=$ nilai atau skor $\mathrm{Y}$

\section{Uji Reliabilitas}

Reliabilitas adalah indeks yang menunjukan sejauhmana suatu alat ukur dapat dipercaya atau diandalkan. Dalam penelitian ini, pengujian reliabilitas menggunakan Alpha cronbachs. Menurut Arikunto (2003:171) rumus digunakan untuk mencari reliabilitas instrumen yang skornya bukan 1 dan 0

$$
\mathrm{r} 11=\left(\frac{\boldsymbol{k}}{\boldsymbol{k}-1}\right)\left(1 \frac{\sum \delta b^{2}}{\delta 1^{2} t}\right)
$$

Keterangan:

$$
\begin{aligned}
& \mathrm{r} 11=\text { reliabilitas Instrumen } \\
& \mathrm{k} \quad=\text { banyaknya butir pernyataan atau banyaknya soal } \\
& \sum \sigma^{2} b=\text { jumlah varaians butir } \\
& \sigma 1^{2} \quad=\text { varians total }
\end{aligned}
$$

Suatu instrument dapat dikatakan reliable jika memiliki nilai koefisien keandalan lebih besar atau sama dengan 0,6 artinya apabila $\alpha=0,6$ maka instrument dapat dikatakan reliabel.

\section{Hasil Uji Validitas dan Relibelitas}

Uji validitas dalam penelitian ini menggunakan rumus korelasi Product Moment Person, dimana valid atau tidaknya instrumen dapat diketahui dengan membandingkan indeks korelasi Product Moment 
Person dengan signifikan 5\%. Artinya bila probabilitas hasil korelasi lebih kecil dari 0,05 maka instrumen dinyatakan tidak valid dan sebaliknya, jika hasil korelasi lebih besar dari 0,05 maka instrumen dinyatakan valid.

Tabel 1.

Pengujian Instrumen Penelitian (Uji Validitas \& Reliabilitas)

\begin{tabular}{|c|c|c|c|c|c|c|}
\hline Variabel & Indikator & Item & Korelasi & Ket & $\begin{array}{c}\text { Alpha } \\
\text { Cronbach }\end{array}$ & Ket \\
\hline \multirow{4}{*}{$\begin{array}{l}\text { Faktor } \\
\text { hubungan } \\
\text { eksekutif dan } \\
\text { legislative }\end{array}$} & \multirow{4}{*}{$\begin{array}{l}\text { - Komunikasi } \\
\text { - Koordinasi }\end{array}$} & $\mathrm{X} 1.1$ & 0.787 & Valid & \multirow{4}{*}{0.797} & \multirow{4}{*}{ Realibel } \\
\hline & & $\mathrm{X} 1.2$ & 0.752 & Valid & & \\
\hline & & $\mathrm{X} 1.3$ & 0.830 & Valid & & \\
\hline & & $\mathrm{X} 1.4$ & 0.800 & Valid & & \\
\hline \multirow{3}{*}{$\begin{array}{l}\text { Faktor latar } \\
\text { belakang } \\
\text { pendidikan }\end{array}$} & \multirow{3}{*}{$\begin{array}{l}\text { - Latar belakang } \\
\text { pendidikan eksekutif } \\
\text { - Latar belakang } \\
\text { pendidikan legislative }\end{array}$} & $\mathrm{X} 2.1$ & 0.815 & Valid & \multirow{3}{*}{0.753} & \multirow{3}{*}{ Realibel } \\
\hline & & $X 2.2$ & 0.828 & Valid & & \\
\hline & & $X 2.3$ & 0.826 & Valid & & \\
\hline \multirow[b]{3}{*}{$\begin{array}{l}\text { Faktorindikator } \\
\text { kinerja }\end{array}$} & \multirow{3}{*}{$\begin{array}{l}\text { - Informasi tentang } \\
\text { indicator kinerja } \\
\text { APBD } \\
\text { - Penentuan indicator } \\
\text { kinerja APBD }\end{array}$} & X3.1 & 0.835 & Valid & \multirow[b]{3}{*}{0.823} & \multirow[b]{3}{*}{ Realibel } \\
\hline & & X3.2 & 0.909 & Valid & & \\
\hline & & X3.3 & 0.834 & Valid & & \\
\hline \multirow{3}{*}{$\begin{array}{l}\text { Faktor } \\
\text { komitmen }\end{array}$} & \multirow{3}{*}{$\begin{array}{l}\text { Penerimaan dan } \\
\text { kepercayaan terhadap } \\
\text { nilai dan tujuan } \\
\text { organisasi }\end{array}$} & $\mathrm{X} 4.1$ & 0.894 & Valid & \multirow{3}{*}{0.818} & \multirow{3}{*}{ Realibel } \\
\hline & & $\mathrm{X} 4.2$ & 0.861 & Valid & & \\
\hline & & $X 4.3$ & 0.824 & Valid & & \\
\hline \multirow{2}{*}{$\begin{array}{l}\text { Faktor } \\
\text { penyusun } \\
\text { APBD }\end{array}$} & \multirow{2}{*}{$\begin{array}{l}\text { - Pendiidkan dan } \\
\text { pelatihan yang } \\
\text { pernah diikuti } \\
\text { - Konflik kepentingan }\end{array}$} & $X 5.1$ & 0.919 & Valid & \multirow[b]{2}{*}{0.829} & \multirow[b]{2}{*}{ Realibel } \\
\hline & & $\times 5.2$ & 0.930 & Valid & & \\
\hline \multirow{5}{*}{$\begin{array}{l}\text { Keterlambatan } \\
\text { penyusunan } \\
\text { APBD }\end{array}$} & \multirow{5}{*}{$\begin{array}{l}\text { - Persepsi hubungan } \\
\text { eksekutif dan } \\
\text { legislative } \\
\text { - Persepsi latar } \\
\text { belakang pendidikan } \\
\text { - Persepsi indikator } \\
\text { kinerja } \\
\text { - Persepsi komitmen } \\
\text { - Persepsi penyusun } \\
\text { APBD }\end{array}$} & Y1.1 & 0.886 & Valid & \multirow[b]{5}{*}{0.914} & \multirow[b]{5}{*}{ Realibel } \\
\hline & & Y1.2 & 0.881 & Valid & & \\
\hline & & Y1.3 & 0.877 & Valid & & \\
\hline & & Y1.4 & 0.875 & Valid & & \\
\hline & & Y1.5 & 0.794 & Valid & & \\
\hline
\end{tabular}

Sumber; Data diolah, (2014) 


\section{Uji Asumsi Klasik}

\section{a. Uji Normalitas}

Salah satu cara untuk mendeteksi normalitas data adalah dengan menggunakan normal probability plot yang pada prinsipnya suatu data ril dikatakan berdistribusi normal jika data ril mengikuti garis diagonal.

\section{b. Uji Multikolinieritas}

Cara mendeteksi ada tidaknya gejala multikolinieritas adalah dengan melihat nilai Variance Inflation Factor (VIF) atau factor pertambahan ragam. Apabilanilai VIF lebih besar dari 10 maka terjadi multikolinieritas, sebaliknya apabila VIF lebih kecil dari 10 maka tidak terjadi multikolinieritas.

\section{c. Uji Heteroskedastisitas}

Priyatno, (2012: 87) menyatakan bahwa model regresi yang baik seharusnya tidak terjadi heteroskedastisitas. Pengujian heteroskedastisitas dalam kajian ini adalah dengan melihat penyebaran titik-titik pada grafik scatter plot yang kriterianya yaitu;

1) Jika ada pola tertentu seperti titik-titik yang ada membentuk suatu pola tertentu yang teratur (bergelombang, melebar kemudian menyempit), maka terjadi heterokedastisitas.

2) Jika tidak ada pola yang jelas, serta titik-titik menyebar diatas dan dibawah angka 0 pada sumbu $\mathrm{Y}$, maka tidak terjadi heterokedastistas.

\section{Analisis Regresi Berganda}

Metode ini digunakan untuk mengetahui variabel yang dominan member sumbangan terhadap variable terikat dan untuk mengetahui pengaruh antara dua variable atau lebih, yaitu variable bebas dan variable terikat. 
Rumusnya (unstandardized coeffi cients) adalah;

$$
Y=a+b_{1} X_{1}+b_{2} X_{2}+b_{3} X_{3}+b_{4} X_{4}+b_{5} X_{5}+\varepsilon
$$

Keterangan;

$\mathrm{Y}=$ Keterlambatan penyusunan APBD

$\alpha=$ Intercept

$\mathrm{b}=$ Koefisienregresi

$X_{1}=\quad$ Faktor hubungan eksekutif dan legislatif

$\mathrm{X}_{2}=\quad$ Faktor latar belakang pendidikan

$\mathrm{X}_{3}=\quad$ Faktor indikator kinerja

$\mathrm{X}_{4}=$ Faktor komitmen

$X_{5}=\quad$ Faktor penyusun APBD

$\varepsilon=$ Residual

\section{Pengujian Hipotesis}

Uji hipotesis dalam penelitian ini menggunakan uji $t$ dengan tingkat signifikannya $5 \%$. Kriteria pengujiannya adalah; jika $t$ nitung $>t$ tabelmaka $\mathrm{HO}$ ditolakdan $\mathrm{Ha}$ diterima artinya terdapat pengaruh variable independen (faktor hubungan eksekutif dan legislatif, faktor latar belakang pendidikan, faktor indikator kinerja, faktor komitmen dan faktor penyusun APBD) terhadap variabel dependen yakni, keterlambatan penyusunan APBD di Kabupaten Sarmi.

\section{HASIL DAN PEMBAHASAN}

\section{Hubungan Eksekutif dan Legislatif}

Hasil pengujian statistik deskriptif tentang faktor hubungan legislatif dan eksekutif dengan menggunakan teknik pengukuran angka indeks rata-rata. 
Tabel 2.

Jawaban Responden Tentang

Faktor Hubungan Eksekutif dan Legislatif

\begin{tabular}{|c|c|c|c|c|c|c|c|c|}
\hline \multirow{3}{*}{ No. } & \multirow{3}{*}{ Item } & \multicolumn{5}{|c|}{ Skor } & \multirow{3}{*}{$\mathrm{Jmh}$} & \multirow{3}{*}{$\begin{array}{l}\text { Rata- } \\
\text { Rata }\end{array}$} \\
\hline & & 5 & 4 & 3 & 2 & 1 & & \\
\hline & & SS & $S$ & $\bar{N}$ & TS & STS & & \\
\hline 1. & $\times 1.1$ & 22 & 34 & 2 & 2 & - & 60 & 4.27 \\
\hline 2. & $\mathrm{X} 1.2$ & 27 & 27 & 6 & - & - & 60 & 4.35 \\
\hline 3. & $\mathrm{X} 1.3$ & 29 & 27 & 4 & - & - & 60 & 4.41 \\
\hline 4. & $\mathrm{X} 1.4$ & 16 & 40 & 4 & - & - & 60 & 4.20 \\
\hline & & & -rat & & & & & 4.31 \\
\hline
\end{tabular}

Sumber; Data diolah, (2014)

Didapatkan hasil skor rata-rata sebesar 4,31 yang berarti bahwa variabel ini mampu dijelaskan dengan sangat baik oleh item-item penyataan diatas atau dapat juga dijustifikasi bahwa responden relatif sangat setuju dengan seluruh pernyataan tentang hubungan yang terjadi antara legislatif dan eksekutif. Item pernyataan yang relatif lebih baik dalam menjelaskan variabel ini adalah item X1.3 yang menyatakan bahwa koordinasi antara eksekutif \& legislatif belum baik.

Variabel hubungan eksekutif dan legislatif terwakili oleh 4 item pernyataan, yakni; komunikasi antar anggota SKPD dalam penyusunan APBD tidak berjalan secara efektif (X1.1), adanya kesenjangan informasi antara eksekutif \&legislatif (X1.2), koordinasi antara eksekutif \& legislatif belum baik (X1.3) dan Eksekutif \& legislatif belum mampu bekerja sama (X1.4). Berdasarkan hasil analisis terlihat bahwa jika faktor hubungan eksekutif dan legislatif semakin baik akan berpotensi mengurangi keterlambatan penyusunan APBD.

\section{Latar Belakang Pendidikan}

Hasil pengujian statistik deskriptif tentang latar belakang pendidikan dengan menggunakan teknik pengukuran angka indeks rata-rata. 
Tabel 3.

Jawaban Responden Tentang Latar Belakang Pendidikan

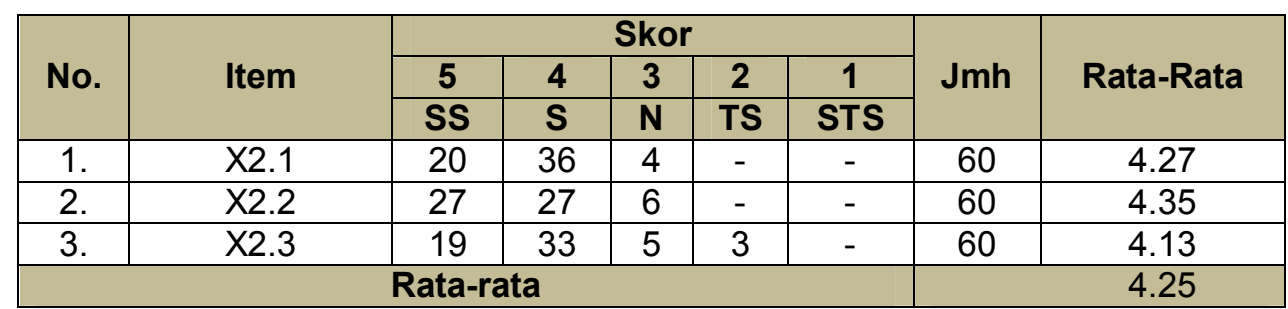

Sumber; Data diolah, (2014)

Didapatkan hasil skor rata-rata sebesar 4,25 yang berarti bahwa variabel ini mampu dijelaskan dengan sangat baik oleh item-item penyataan diatas atau dapat juga dijustifikasi bahwa responden relatif sangat setuju dengan seluruh pernyataan tentang latar belakang pendidikan penyusun APBD. Item pernyataan yang relatif lebih baik dalam menjelaskan variabel ini adalah item X2.2 yang menyatakan bahwa anggota Badan Anggaran (Banggar) minim dengan latar belakang pendidikan terkait penganggaran daerah.

Hasil analisis juga menunjukan bahwa faktor latar belakang penelitian juga turut mempengaruhi keterlambatan peyusunan APBD, artinya bahwa jika sumberdaya manusia dalam hal ini penyusun APBD tidak memiliki latar belakang pendidikan yang memadai maka akan berpotensi menyebabkan keterlambatan dalam penyusunan APBD tersebut. Hal ini seharusnya dapat dihindari atau minimal dapat direduksi karena apabila sumber daya manusia yang melaksanakan penyusunan APBD tidak memiliki kualitas yang disyaratkan, maka akan menimbulkan hambatan dalam pelaksanaan tugasnya, dan akhirnya APBD sebagai produk dari perencanaan dan sistem akuntansi, kualitasnya menjadi buruk, Informasi yang dihasilkan menjadi informasi yang kurang atau tidak memiliki nilai (Dita Arfianti, 2011) 


\section{Indikator Kinerja}

Hasil pengujian statistik deskriptif tentang indikator kinerja dengan menggunakan teknik pengukuran angka indeks rata-rata.

Tabel 4.

Jawaban Responden Tentang Indikator Kinerja

\begin{tabular}{|c|c|c|c|c|c|c|c|c|}
\hline \multirow{3}{*}{ No. } & \multirow{3}{*}{ Item } & \multicolumn{5}{|c|}{ Skor } & \multirow{3}{*}{$\mathrm{Jmh}$} & \multirow{3}{*}{ Rata-Rata } \\
\hline & & 5 & 4 & 3 & 2 & 1 & & \\
\hline & & SS & $\mathbf{S}$ & $\mathbf{N}$ & TS & STS & & \\
\hline 1. & X3.1 & 17 & 38 & 5 & - & - & 60 & 4.20 \\
\hline 2. & $\mathrm{X} 3.2$ & 23 & 33 & 2 & 2 & - & 60 & 4.28 \\
\hline 3. & $\mathrm{X} 3.3$ & 14 & 41 & 4 & 1 & - & 60 & 4.13 \\
\hline & & Rata & & & & & & 4.20 \\
\hline
\end{tabular}

Sumber; Data diolah, (2014)

Didapatkan hasil skor rata-rata sebesar 4,20 yang berarti bahwa variabel ini mampu dijelaskan dengan baik oleh item-item penyataan diatas atau dapat juga dijustifikasi bahwa responden relatif setuju dengan seluruh pernyataan tentang indikator kinerja. Item pernyataan yang relatif lebih baik dalam menjelaskan variabel ini adalah item X3.2 yang menyatakan bahwa informasi pemda dalam menentukan indikator kinerja pada APBD masih dirasakan kurang.

Hasil analisis berikutnya menyangkut variabel indikator kinerja yang diukur melalui item; (1) kesulitan menerjemahkan indikator kinerja dalam APBD, (2) kurangnya informasi pemda dalam menentukan indikator kinerja pada APBD dan (3) komunikasi antar anggota SKPD dalam menyusun APBD tidak efektif, menunjukan bahwa variabel tersebut juga berpengaruh terhadap keterlambatan peyusunan APBD. Hal ini berarti bahwa jika indikator kinerja meningkat atau semakin baik maka akan mengurangi potensi terjadinya keterlambatan penyusunan APBD atau dapat dijustifikasi bahwa dorongan peningkatan indikator kinerja akan mengurangi potensi terjadinya keterlambatan penyusunan APBD. 


\section{Komitmen}

Hasil pengujian statistik deskriptif tentang komitmen dengan menggunakan teknik pengukuran angka indeks rata-rata.

Tabel 5.

Jawaban Responden Tentang Komitmen

\begin{tabular}{|c|c|c|c|c|c|c|c|c|}
\hline \multirow{3}{*}{ No. } & \multirow{3}{*}{ Item } & \multicolumn{5}{|c|}{ Skor } & \multirow{3}{*}{$\mathrm{Jmh}$} & \multirow{3}{*}{ Rata-Rata } \\
\hline & & 5 & 4 & 3 & 2 & 1 & & \\
\hline & & SS & $S$ & $\mathbf{N}$ & TS & STS & & \\
\hline 1. & $X 4.1$ & 21 & 34 & 2 & 3 & - & 60 & 4.21 \\
\hline 2. & $\mathrm{X} 4.2$ & 19 & 37 & 4 & - & - & 60 & 4.25 \\
\hline 3. & X4.3 & 16 & 38 & 6 & - & - & 60 & 4.17 \\
\hline & & Ratc & & & & & & 4.21 \\
\hline
\end{tabular}

Sumber; Data diolah, (2014)

Didapatkan hasil skor rata-rata sebesar 4,21 yang berarti bahwa variabel ini mampu dijelaskan dengan sangat baik oleh item-item penyataan diatas atau dapat juga dijustifikasi bahwa responden relatif sangat setuju dengan seluruh pernyataan tentang komitmen penyusun APBD. Item pernyataan yang relatif lebih baik dalam menjelaskan variabel ini adalah item X4.2 yang menyatakan bahwa penyusun APBD dari SKPD belum memahami visi, misi, sasaran, \& tujuan dari penyusunan APBD dengan baik.

Hasil analisis lainnya menyangkut faktor komitmen menunjukan bahwa faktor ini tidak berpengaruh positif terhadap keterlambatan penyusunan APBD. Pengaruh positif ini menunjukkan bahwa pengaruh komitmen dari seluruh komponen organisasi adalah searah dengan penyusunan APBD atau dengan kata lain adanya komitmen dari seluruh komponen organisasi yang tinggi maka akan berpengaruh pada tingkat keberhasilan penyusunan APBD. 


\section{Penyusun APBD}

Hasil pengujian statistik deskriptif tentang penyusun APBD dengan menggunakan teknik pengukuran angka indeks rata-rata.

Tabel 6.

Jawaban Responden Tentang Penyusun APBD

\begin{tabular}{|c|c|c|c|c|c|c|c|c|}
\hline \multirow{3}{*}{ No. } & \multirow{3}{*}{ Item } & \multicolumn{5}{|c|}{ Skor } & \multirow{3}{*}{ Jmh } & \multirow{3}{*}{ Rata-Rata } \\
\hline & & 5 & 4 & 3 & 2 & 1 & & \\
\hline & & SS & S & $\mathbf{N}$ & TS & STS & & \\
\hline 1. & $\times 5.1$ & 11 & 45 & 3 & 1 & - & 60 & 4.10 \\
\hline 2. & $\times 5.2$ & 21 & 35 & 4 & - & - & 60 & 4.28 \\
\hline \multicolumn{7}{|c|}{ Rata-rata } & & 4.19 \\
\hline
\end{tabular}

Sumber; Data diolah, (2014)

Didapatkan hasil skor rata-rata sebesar 4,19 yang berarti bahwa variabel ini mampu dijelaskan dengan baik oleh item-item penyataan diatas atau dapat juga dijustifikasi bahwa responden relatif setuju dengan seluruh pernyataan tentang penyusun APBD. Item pernyataan yang relatif lebih baik dalam menjelaskan variabel ini adalah item X5.2 yang menyatakan bahwa pihak legislatif lebih mengutamakan kepentingan legislatif dalam penyusunan APBD.

Hasil analisis yang terakhir mengenai faktor penyusun APBD ternyata juga menunjukan bahwa faktor ini berpengaruh positif terhadap keterlambatan penyusunan APBD. Hal ini relative disebabkan kerena penyusun APBD telah dibekali dengan pengetahuan yang baik melalui kegiatan pelatihan atau pendidikan yang terkait dengan penganggaran dan tidak terjadi konflik kepentingan diantara penyusun APBD tersebut. Pengaruh positif menunjukkan bahwa peran sumberdaya manusia (dalam hal ini adalah penyusun APBD) dalam keberhasilan penyusunan APBD juga penting. Penelitian ini sejalan dengan teori Edward III, (1980) dalam Akib, (2010) bahwa sumber daya merupakan hal penting dalam implementasi kebijakan yang baik dimana indikator-indikator yang 
digunakan untuk melihat sejauhmana sumberdaya mempengaruhi implementasi kebijakan terdiri dari; sumberdaya manusia, sumberdaya anggaran, informasi berupa data dan fasilitas pendukung lainnya.

\section{Keterlambatan Penyusunan APBD}

Hasil pengujian statistik deskriptif tentang keterlambatan penyusunan APBD dengan menggunakan teknik pengukuran angka indeks rata-rata.

Tabel 7.

Jawaban Responden Tentang Keterlambatan Penyusunan APBD

\begin{tabular}{|c|c|c|c|c|c|c|c|c|}
\hline \multirow{3}{*}{ No. } & \multirow{3}{*}{ Item } & \multicolumn{5}{|c|}{ Skor } & \multirow{3}{*}{ Jmh } & \multirow{3}{*}{ Rata-Rata } \\
\hline & & 5 & 4 & 3 & 2 & 1 & & \\
\hline & & SS & S & $\mathbf{N}$ & TS & STS & & \\
\hline 1. & YI.1 & 22 & 34 & 4 & - & - & 60 & 4.31 \\
\hline 2. & YI.2 & 19 & 37 & 2 & 2 & - & 60 & 4.22 \\
\hline 3. & YI.3 & 21 & 35 & 4 & - & - & 60 & 4.28 \\
\hline 4. & YI.4 & 22 & 34 & 4 & - & - & 60 & 4.30 \\
\hline 5. & YI.5 & 18 & 38 & 4 & - & - & 60 & 4.23 \\
\hline \multicolumn{7}{|c|}{ Rata-rata } & \multicolumn{2}{|r|}{4.26} \\
\hline
\end{tabular}

Sumber; Data diolah, (2014)

Didapatkan hasil skor rata-rata sebesar 4,26 sangat yang berarti bahwa variabel ini mampu dijelaskan dengan baik oleh item-item penyataan diatas atau dapat juga dijustifikasi bahwa responden relatif sangat setuju dengan seluruh pernyataan tentang keterlambatan penyusunan APBD. Item pernyataan yang relatif lebih baik dalam menjelaskan variabel ini adalah item Y1.1 yang menyatakan bahwa faktor hubungan eksekutif dan legislatif yang relatif baik akan mencegah keterlambatan penyusunan APBD.

\section{Analisis Regresi Berganda}

Berikut ini adalah hasil pengujian dengan menggunakan analisis regresi sederhana dengan menggunakan bantuan software SPSS (Statistikal Package for Social Science) versi 21.0. seperti yang terlihat pada Tabel 8 dibawah ini. 
Tabel 8.

Hasil Analisis Regresi

\begin{tabular}{|l|c|c|c|c|}
\hline \multicolumn{1}{|c|}{ Variabel } & $\begin{array}{c}\text { Standardized } \\
\text { Coefficients }\end{array}$ & $\mathbf{t}$ hitung & Sig & Keterangan \\
\hline Constant & 0.350 & \multicolumn{5}{|c|}{} \\
\hline $\begin{array}{l}\text { Faktor hubungan } \\
\text { eksekutif dan legislatif }\end{array}$ & 0.186 & 2.758 & 0.008 & Signifikan \\
\hline $\begin{array}{l}\text { Faktor latar belakang } \\
\text { pendidikan }\end{array}$ & 0.295 & 2.027 & 0.048 & Signifikan \\
\hline Faktor indikator kinerja & 0.416 & 2.153 & 0.036 & Signifikan \\
\hline Faktor komitmen & 0.365 & 1.817 & 0.075 & $\begin{array}{c}\text { Tidak } \\
\text { Signifikan }\end{array}$ \\
\hline Faktor penyusun APBD & 0.496 & 2.075 & 0.043 & Signifikan \\
\hline R Square & \multicolumn{5}{|c|}{0.960} \\
\hline Ajusted R Square & \multicolumn{5}{|c|}{1.671} \\
\hline $\mathrm{t}$ tabel & \multicolumn{5}{|c|}{} \\
\hline
\end{tabular}

Sumber: Data diolah, (2014)

Data pada Tabel 8 diatas menunjukan nilai konstanta sebesar 0.350mengartikan mengartikan bahwa jika tidak ada kenaikan nilai dari seluruh variabel independen (faktor hubungan eksekutif dan legislatif, latar belakang pendidikan, indikator kinerja, komitmen dan penyususn APBD)maka besarnya adalah nilai variabel keterlambatan penyusunan APBD adalah sebesar 0.350 .

Koefisien regresi faktor hubungan eksekutif dan legislatif sebesar 0.186menunjukkan bahwa setiap variabel faktor hubungan eksekutif dan legislatif meningkat atau semakin baik maka variabel keterlambatan penyusunan APBD akan meningkat sebesar nilai koefisien tersebutatau dengan kata lain setiap peningkatan variabel keterlambatan penyusunan APBD dibutuhkanvariabel faktor hubungan eksekutif dan legislatifsebesar 0.186 .

Koefisien regresi faktor latar belakang pendidikan sebesar 0.295 menunjukkan bahwa setiap variabel faktor latar belakang pendidikan 
meningkat atau semakin baik maka variabel keterlambatan penyusunan APBD akan meningkat sebesar nilai koefisien tersebutatau dengan kata lain setiap peningkatan variabel keterlambatan penyusunan APBD dibutuhkanvariabel faktor latar belakang pendidikan sebesar 0.295.

Koefisien regresi indikator kinerja sebesar 0.416 menunjukkan bahwa setiap variabel indikator kinerjameningkat atau semakin baik maka variabel keterlambatan penyusunan APBD akan meningkat sebesar nilai koefisien tersebutatau dengan kata lain setiap peningkatan variabel keterlambatan penyusunan APBD dibutuhkanvariabel indikator kinerjasebesar 0.416 .

Koefisien regresi komitmen sebesar 0.365 menunjukkan bahwa setiap variabel komitmen meningkat atau semakin baik maka variabel keterlambatan penyusunan APBD akan meningkat sebesar nilai koefisien tersebut atau dengan kata lain setiap peningkatan variabel keterlambatan penyusunan APBD dibutuhkan variabel komitmen sebesar 0.365 .

Koefisien regresi faktor penyusun APBD sebesar 0.496 menunjukkan bahwa setiap variabel faktor penyusun APBD meningkat atau semakin baik maka variabel keterlambatan penyusunan APBD akan meningkat sebesar nilai koefisien tersebutatau dengan kata lain setiap peningkatan variabel keterlambatan penyusunan APBD dibutuhkanvariabel faktor penyusun APBD sebesar 0.496 .

Data Tabel 5 diatas juga menunjukan bahwa model konseptual penelitian yang dibangun adalah layak karena terbukti variabel keterlambatan penyusunan APBD dapat dijelaskan oleh variabel; faktor hubungan eksekutif dan legislatif, latar belakang pendidikan, indikator kinerja, komitmen dan penyususn APBD dengan nilai determinasi atau 
tingkat kelayakan model yang baik yakni sebesar 0.956 atau sebesar $95.6 \%$ sementara $4.4 \%$ lainnya dijelaskan oleh variabel lain yang tidak diuji dalam model konseptual penelitian ini.

\section{KESIMPULAN DAN SARAN}

\section{Kesimpulan}

a. Faktor hubungan eksekutif dan legislatif terbukti berpengaruh positif terhadap keterlambatan penyusunan. APBD pada Kabupaten Sarmi atau dapat dikatakan bahwa dorongan peningkatan faktor hubungan eksekutif dan legislatif yang semakin baik akan berpotensi mengurangi keterlambatan penyusunan APBD pada Kabupaten Sarmi.

b. Faktor latar belakang pendidikan terbukti berpengaruh positif terhadap keterlambatan penyusunan APBD pada Kabupaten Sarmi atau dapat dikatakan bahwa dorongan peningkatan factor latar belakang pendidikan yang semakin baik akan berpotensi mengurangi keterlambatan penyusunan APBD pada Kabupaten Sarmi.

c. Faktor indiktor kinerja terbukti berpengaruh positif terhadap keterlambatan penyusunan APBD pada Kabupaten Sarmi atau dapat dikatakan bahwa dorongan peningkatan faktor indicator kinerja yang semakin baik akan berpotensi mengurangi keterlambatan penyusunan APBD pada Kabupaten Sarmi.

d. Komitmen terbukti tidak berpengaruh terhadap keterlambatan penyusunan APBD pada Kabupaten Sarmi atau dapat dikatakan bahwa dorongan peningkatan komitmen yang semakin baik akan berpotensi mengurangi keterlambatan penyusunan APBD pada Kabupaten Sarmi.

e. Faktor penyusun APBD terbukti berpengaruh positif terhadap keterlambatan penyusunan APBD pada Kabupaten Sarmi atau dapat dikatakan bahwa dorongan peningkatan faktor penyusun 
APBD yang semakin baik akan berpotensi mengurangi keterlambatan penyusunan APBD pada Kabupaten Sarmi.

\section{Saran}

Saran yang dapat diberikan melalui hasil kajian ini adalah sebagai berikut;

a. Pada tahapan penyusunan APBD, membina hubungan yang harmonis dan bersinergi antara eksekutif maupun legislative perlu dilakukan secara mendalam dan menyeluruh. Kedua belah pihak tersebut harus memahami tujuan dari penyusunan APBD Kabupaten Sarmi bagi pelaksanaan pemerintahan dan setiap unsur yang terlibat haruslah berkomitmen untuk memberikan yang terbaik dalam penyusunan APBDdi Kabupaten Sarmi.

b. Kompetensi dan keahlian sumber daya manusia harus menjadi perhatian utama bagi Pemeritah Kabupaten Sarmi dalam khususnya penyusunan APBD. Penempatan pegawai hendaknya didasarkan pada pertimbangan bahwa pegawai tersebut memiliki keahlian dan kompetensi terkait dengan tugas dan kegiatan yang harus dilakukan tersebut dengan tujuan pelaksanaan yang efektif dan efisien.

c. Pemerintah Kabupaten Sarmi sebaiknya dapat secara mandiri menyelenggarakan pendidikan dan pelatihan yang terkait dengan penganggaran keuangan daerah. Adanya hal tersebut dapat menambah kompetensi dan keahlian pihak yang telah berlatar pendidikan terkait penganggaran keuangan daerah serta memberikan tambahan ilmu baru bagi pihak yang belum berkompeten dalam hal tersebut.

d. Faktor-faktor yang telah teridentifikasi tersebut dapat menjadi dasar bagi pihak eksekutif maupun legislatif untuk merancang solusi penyelesaian terhadap pencegahan terjadinya keterlambatan penyusunan APBD di Kabupaten Sarmi dimasa mendatang. 


\section{DAFTAR PUSTAKA}

Chitra Ariesta Pandan Wangi dan Irwan Taufiq Ritonga. 2010. Identifikasi Faktor-Faktor Penyebab Terjadinya Keterlambatan Dalam Penyusunan APBD (Studi Kasus Kabupaten rejang Lebong Tahun Anggaran 2008-2010), Simposium Nasional Akuntansi XIII, Purwokerto.

Dita Arfianti. 2011. Analisis Faktor-Faktor yang Mempengaruhi Nilai Informasi Pelaporan Keuangan Pemerintah Daerah (Studi pada SKPD di Kabupaten Batang), Skripsi, Fakultas Ekonomi Universitas Diponegoro.

Gribaldi. 2008. Otonomi Daerah dan Paradigma Baru Penyusunan APBD, Jurnal ISSN; 1979-0899X, Volume 1, Nomor 2, Desember 2008.

Kunwaviyah dan Machmud. 2010. Peran Variabel Komitmen Organisasi dan Inovasi pada Hubungan Penganggaran dan Kinerja. Jurnal Akuntansi dan Auditing, Vol 7 No 1, 2010.

Muhammad T. Andika. 2006. Birokrasi dan Keterlambatan APBD, Surat Kabar Seputar Indonesia, Selasa, 10 Oktober 2006, Hal. 7, Kolom 3-7.

Norsain. 2010. Identifikasi Faktor-Faktor Penyebab Terjadinya Keterlambatan Dalam Penyusunan APBD (Studi Kasus Kabupaten Semenep Tahun Anggaran 2007-2010), Tesis, Program Pasca Sarjana Universitas Pembangunan Nasional "Veteran", Jawa Timur.

Nurwira Rahayu Mubar, Muhammad Ali dan Nurjannah Hamid. 2011. Faktor-Faktor yang Mempengaruhi Penyusunan APBD Berbasis Kinerja, Skripsi, Fakultas Ekonomi Universitas Hasanuddin.

Republik Indonesia. 2005. Peraturan Pemerintah Nomor 58 Tahun 2005 tentang Pengelolaan Keuangan Daerah.

2006. Peraturan Menteri Dalam Negeri Nomor 13 Tahun 2006, Tentang Struktur Anggaran Pendapatan dan Belanja Daerah (APBD).

Sardjito, Bambang, Muthaher, Osmad, (2007) Pengaruh Partisipasi Penyusunan Anggaran Terhadap Kinerja Aparat Pemda : Budaya dan Komitmen Organisasi sebagai Variabel 
Moderating. Simposium Nasional Akuntansi X, 26-28 Juli. Makassar.

Solihin Dadang, (2011) Penyusunan Anggaran Berbasis Kinerja. Bimbingan Teknis Perencana Bappeda Provinsi DKI Jakarta. Jakarta : Bappenas.

Sopiah,(2008) Perilaku Organisasional, Yogyakarta, Andi.

Sri Wahyuni, (2010) Analisis Faktor-Faktor Keterlambatan Dalam Penyusunan APBD (Studi Kasus di Kabupaten Sukamara), Penelitian Mandiri.

Suhartono, Ehrmann, Solichin, Mochammad, (2007) Pengaruh Kejelasan Sasaran Anggaran Terhadap Kesenjangan Anggaran Instansi Pemerintah Daerah dengan Komitmen Organisasi sebagai Pemoderasi, Jurnal Akuntansi dan Keuangan Sektor Publik, Vol 08, No 01, Jogjakarta.

Sumarno, (2005) Pengaruh Komitmen Organisasi dan Gaya Kepemimpinan Terhadap Hubungan Antara Partisipasi Anggaran dan Kinerja Manajerial, Simposium Nasional Akuntansi VIII, 15-16 September, Solo. 